УДК 159.923.5+316.624

В. Р. ПАВЕЛКІВ

\title{
ДІАГНОСТИЧНИЙ КОМПОНЕНТ ДОСЛІДЖЕННЯ ОСОБИСТІСНИХ ДЕСТРУКЦЙ ПРЕДСТАВНИКІВ МОЛОДІжНИХ СУБКУЛЬТУР
}

У статті представлений науково-теоретичний огляд вітчизняних $і$ зарубіжних досліджень, присвячених проблемі впливу сочіальних чинників на процес формування особистісних деструкиій молоді у системі молодіжних субкультур.

Здійснено спробу розкрити вплив середовища молодіжних субкультур як психологічної детермінанти формування деструкиій, а також представлено методи $і$ засоби психодіагностики компонентів особистісних деструкцій у представників молодіжних субкультур, що стає головним джерелом теоретико-методологічного пошуку автора. На емпіричному рівні встановлено сутність і взаємозв'язок механізмів формування деструктивних форм реагування особистості та їх прояви у соиіальній взаємодії.

Розглянуто сочіально-психологічні особливості впливу молодіжної субкультури на особистість підлітка як однієї з рушійних сил формування особистісних деструкцій. Здійснено аналіз соиіальних відхилень поведінки особистості, які формуються під впливом молодіжних угруповань, а також аналіз теорії причин виникнення відхилень.

Представлений аналіз забезпечує системне уявлення про особистісні деструкиї̈ молоді та забезпечує розкриття причинно-наслідкового зв'язку впливу соиіального середовища на особистість.

Ключові слова: субкультура, молодіжна субкультура, особистісні деструкиї, деформаџія особистості, деформована соиіалізачія.

В статье представлен научно-теоретический обзор отечественных и зарубежных исследований, посвященных проблеме влияния социальных факторов на процесс формирования личностных деструкиий молодежи в системе молодежных субкультур. 
Предпринята попытка раскрыть влияние среды молодежных субкультур как психологической детерминанты формирования деструкции, а также представлены методы $u$ средства психодиагностики компонентов личностных деструкиий у представителей молодежных субкультур, что становится главным источником теоретико-методологического поиска автора. На эмпирическом уровне установлено сущность и взаимосвязь механизмов формирования деструктивных форм реагирования личности и их проявления в сочиальном взаимодействии.

Рассмотрень сочиально-психологические особенности воздействия молодежной субкультуры на личность подростка как одной из движущих сил формирования личностных деструкичий. Осуществлен анализ сочиальных отклонений поведения личности, которые формируются под влиянием молодежных группировок, а также анализ теории причин возникновения отклонений.

Представленный анализ обеспечивает системное представление о личностных деструкиии молодежи и обеспечивает раскрытие причинно-следственной связи влияния социальной среды на личность.

Ключевые слова: субкультура, молодежная субкультура, личностные деструкиии, деформация личности, деформированая сочиализачия.

Постановка проблеми. В умовах трансформаційного суспільства, коли старі цінності відкинуті, а нові не сформовані, особливої уваги набуває питання соціалізації молоді. Процес соціалізації є важливим як на рівні кожної конкретної особистості, так і на рівні соціальної групи і суспільства в цілому. Водночас соціологи та психологи відмічають зростання рівня молодіжних контркультурних об'єднань 3 яскраво вираженою деструктивною спрямованістю поведінки, що криє в собі небезпеку десоціалізації та деградації соціальної спрямованості індивідів у дорослому житті. У цьому контексті варто відзначити неповне теоретичне вивчення, зокрема у рамках психології, деструктивних проявів у молодіжному субкультурному середовищі, так само як і недостатню розробленість, а часом і відсутність методичного забезпечення психологів для роботи з підліткаминеформалами.

Дослідження деструктивної поведінки в субкультурах особливо актуальне з огляду на те, що особистісна деструктивність є невід’ємною характеристикою представників молодіжних субкультур.

Аналіз останніх досліджень та публікацій. У численних дослідженнях використовуються різні концепції та моделі виникнення і розвитку особистісних деструкцій з точки зору психологопедагогічних, біологічно-медичних та соціокультурних підходів.

Проблема деструктивних змін особистості недостатньо досліджена в науці. Серед вчених, що займаються вивченням різних особистісних патологій, немає термінологічної єдності. Починаючи 3 XIX ст. в науці традиційно використовуються такі терміни, як «деперсоналізація», «дереалізація», «деіндивідуалізація», «дегенерація» особистості. Деперсоналізація вперше була розглянута Л. Дюгасом в 1889 р. Він розумів під деперсоналізацією «почуття втрати власної особистості». Творець психоаналізу 3. Фрейд, відзначав, що самовідчуження веде до невротичної втрати свого власного «Я» - деперсоналізації, або до втрати почуття реальності навколишнього світу дереалізації. Американський соціолог Ч. Кулі пропонував використовувати термін «дегенерація особистості» для опису стану тих людей, характер і поведінку яких знаходяться явно нижче зразка або рівня, що розцінюються в який панує думці групи в якості норми: розумово відсталі, божевільні, алкоголіки і злочинці. Найбільш широко в сучасній патопсихології та психіатрії використовується поняття «деперсоналізація», однак воно не має однозначних трактувань. Так, А. Меграбян відзначав, що поняття «деперсоналізація» в широкому сенсі слова включає в себе і дереалізації, так як під порушенням особистості даного типу ми розуміємо не тільки порушення здатності усвідомлення свого «Я» і свого тіла, але і порушення здатності усвідомлення реальності об'єктивного світу. Деперсоналізаційні розлади характеризуються психічним автоматизмом, явищами відчуження психічних процесів. Інші дослідники відносять до деперсоналізації порушення схеми тіла і психосенсорні розлади (М. Гуревич, Р. Голант), стану «dejavu» (А. Шмарьян). Ю. Нуллер розуміє під деперсоналізацією відчуття зміни власного «Я» 3 втратою емоційного компонента психічних процесів [4, с. 66].

У психології обгрунтовано, що формування особистісних деструкцій відбувається не «природними механізмами», а зумовлюються соціально-психологічними чинниками, зокрема особливостями мікросередовища, груповими взаємини, недоліками виховання тощо.

Формулювання цілей статті. Метою даної статті є систематизація науково-психологічних знань про прояви особистісних деструкцій учасників молодіжних субкультур. Емпіричне 
дослідження впливу субкультури на особистість, детермінант і змісту деструктивної трансформації особистості.

Виклад основного матеріалу дослідження. Поведінкові реакції особистості значною мірою залежать від постійних та сильнодіючих зовнішніх впливів і внутрішнього сприйняття нею певних соціально-правових категорій, які превалюють у суспільстві. Взаємне підсилення дії зовнішніх та внутрішніх чинників негативної соціалізації особистості сприяє закріпленню проявів агресії та провокує трансформацію в деструктивну форму.

Асоціальний досвід і мотиви асоціальної діяльності покладені в основу багатьох типологій неформальних молодіжних субкультур. А. Мудрик вважає, що в асоціальних субкультурах залежно від умов життя і ціннісних орієнтацій їх носіїв присутні більш-менш трансформовані громадські та частково антигромадські норми [5, с. 135]. I. Башкатов, виділяючи асоціальне неформальне об'єднання молодих людей, говорить про наявність в них групових асоціальних цінностей і норм, наявності особливого стилю життя, символіки, сленгу, про ситуативний характер асоціальних дій і про відсутність криміногенної спрямованості [3, с. 19]. Західний дослідник М. Брейк [6, с. 23] розглядає молодіжні субкультури з погляду девіантності і характеризує як делінквентну групу, що поєднує тих, хто потенційно здатен вчинити протиправні дії. Слідом за дослідниками під асоціальної молодіжною субкультурою, розуміємо об'єднання молодих людей, які поділяють асоціальні цінності і норми та вступають у зв'язку з цим у соціальний конфлікт з домінуючими суспільними традиціями. Наслідком входження в субкультуральне середовище $\epsilon$ переорієнтація незакріплених у повсякденній діяльності ціннісних орієнтації позитивного плану або первинне формування негативних соціальних установок через конформність юнацького віку Внаслідок цього створюються передумови зниження рівня позитивно забарвлених соціальних домагань і референтних орієнтації, а тому субкультурне оточення виступає фактором ризику формування агресивної поведінки [1].

Деструктивні особистісні зміни, що порушують цілісність особистості, знижують іiі адаптивність і стійкість, можна визначити, як соціально обумовлені деформації сформованої структури діяльності й особистості, що позначаються на продуктивності праці та взаємодії з іншими учасниками соціального процесу [2].У процесі формування асоціальних установок внаслідок багаторазових повторень відбувається трансформація потреб (зміна ціннісних орієнтацій особистості), деструктивна поведінка закріплюється, стає звичною, слабо контролюється свідомістю, навіть може стати потребою.

Відповідно до аналізу формування особистісних деструкцій предстаників молодіжних субкультур в ході емпіричного дослідження вирішувалися наступні завдання:

1. Вивчення особливостей особистісних деструкцій підлітків-неформалів.

2. Аналіз впливу соціального середовища на розвиток різних форм особистісних деструкцій.

Для дослідження деструктивних проявів було застосовано авторський опитувальник «Суб’єктивна методика дослідження особистісних деструкцій представників молодіжних субкультур». Опитувальник складається зі 100 питань-суджень, які поділені на 5 базових складових особистісних деструкцій: агресивність, конфліктність, тривожність, дезадаптація, схильність до девіантної поведінки. Оцінка отриманих в результаті дослідження даних базується на даних статистично підтвердженої дискретної значущості кожної відповіді в порівнянні 3 середньо нормативними показниками.

СУБ'ЄКТИВНА МЕТОДИКА ДОСЛІДЖЕННЯ ОСОБИСТІСНИХ ДЕСТРУКЦІЙ ПРЕДСТАВНИКІВ МОЛОДІЖНИХ СУБКУЛЬТУР

Інструкція: Уважно прочитайте кожне висловлювання. Якщо воно підходить Вам, поставте поруч знак «+», якщо не підходить, то «-». Якщо твердження по відношенню до Вас буває і вірно і невірно, то вибирайте рішення відповідно до того, що буває частіше або ж так, як це правильно в теперішній час. Можливо, деякі твердження Вам буде важко віднести до собе, тоді постарайтеся зробити найкращий можливий вибір.Ваша відповідь повинна відображати тільки Ваше власну думку. Це не випробування розуму чи здібностей, і тут немає ні хороших, ні поганих відповідей. Не витрачайте час на роздуми. Найбільш природна та реакція, яка першою приходить на думку.

\section{Текст опитувальника}

1. Я такий же спроможний і кмітливий, як і більшість людей.

2. Я товариська, відкрита людина і легко спілкуюся з іншими.

3. Часто відчуваю себе пригніченим.

4. Зазвичай я прокидаюся відпочившим.

5. Я рідко хвилююсь про стан здоров'я.

6. Часто відчуваю смуток.

7. Моє життя сповнене цікавих подій. 
8. Щоб отримати задоволення, необхідно порушити деякі правила і заборони.

9. І Інколи я думаю про щось дуже погане.

10. 3 оточуючими я вільно спілкуюся, не відчуваючи дискомфорту.

11. Не маю бажання розкриватися перед іншими.

12. Часом я впевнений у власній непотрібності.

13. У мене добра пам'ять.

14. Мені подобається читати профільну літературу.

15. Я став гірше розуміти зміст прочитаного.

16. Я маю до себе високі вимоги.

17. Коли я стою на мосту, то хочу стрибнути вниз.

18. Можна не зважати на закони, якщо тобі щось дуже потрібно.

19. Я готовий до захисту або, навіть, до нападу.

20. Маю сумніви, що можу подобатися особам протилежної статі.

21. Якщо відчуваєш сильний статевий потяг, то можна не зважати на правила і заборони.

22. Умію керувати собою і власними вчинками.

23. Коли треба щось зробити, мене охоплюють страх та сумніви.

24. У мене бувають періоди розпачу та небажання працювати.

25. Я відповідально ставлюся до всіх справ.

26. Від мене нічого не залежить.

27. Я в цілому дотримуюся правил й вимог встановлених у суспільстві.

28. Я П приймаю кожного таким, яким він $є$.

29. Я відчуваю неприязнь до всього, що мене оточує.

30. Мені важко зосередитися на певній роботі.

31. Мені легко, спокійно на душі, немає нічого, що сильно хвилювало б.

32. У мене напружене життя.

33. Я хочу усе покинути і кудись сховатися.

34. Зазвичай я засинаю без тривожних думок.

35. Мені, безперечно, не вистачає впевненості.

36. Перед тим як щось зробити, я добре поміркую та проаналізую всі можливі рішення.

37. Я боюся увійти в кімнату з великою кількістю людей.

38. Іноді я досить довго не можу прийняти рішення, потім маю сумніви щодо його правильності.

39. Я часто здійснюю вчинки про, які потім жалкую.

40. Я не думаю про свої проблеми.

41. Мені рідко сняться сни.

42. Дрібниці мене не засмучуюсь.

43. Я не соромлюся своїх почуттів, відкрито їх виражаю.

44. Майже кожного дня трапляється щось, що лякає мене.

45. Мені важко говорити перед великою кількістю людей.

46. У спірній ситуації, я спокійно реагую на всі вислови і ввічливо поясню свою точку зору.

47. Якщо хтось не хоче прийняти мою точку зору, то я примушу це зробити.

48. Коли я злюся, то не вдаюся до лайки.

49. Завжди слід доводити свою точку зору.

50. Я завжди схиляюсь до прямого обговорення проблеми.

51. Якщо я не схвалюю поведінку друзів, то відверто заявляю їм про це.

52. Як правило, я заклопотаний тим, щоб задовольнити бажання кожного.

53. Я намагаюся не сперечатися.

54. Коли я довожу свою правоту, на дискомфорт партнерів не звертаю уваги.

55. Під час суперечки я часто підвищую голос.

56. Мені подобається ретельно продумувати, як вплинути на інших людей, щоб вони допомогли мені досягти моєї цілі.

57. Люди дратують мене своєю присутністю.

58. Я поблажливий до чужих недоліків.

59. Я не згоден, що мати владу над людьми - найважливіша цінність.

60. Я дуже дратівливий.

61. Я стараюся не зачепити почуттів іншого.

62. Я грубуватий стосовно людей, які мені не подобаються. 
63. Якщо моє вдале зауваження залишиться непоміченим, то я повторюю своє зауваження знову, щоб на це звернули увагу.

64. Я вимагаю, щоб люди ставилися до мене з повагою.

65. Я намагаюся улагодити справу з урахуванням інтересів іншого і моїх власних.

66. Я можу першим розпочати бійку.

67. Часом я маю нестримне бажанням завдати шкоди іншим.

68. Якщо хтось розсердиться на мене, то я розізлюсь на нього у відповідь.

69. Мене легко роздратувати, але я швидко заспокоююсь.

70. Потрібно прагнути зрозуміти людину, і вона відповість добром.

71. Іноді я б'юся.

72. Коли хтось намагається керувати мною, я навмисне роблю все навпаки.

73. І Іноді для захисту себе я застосовую фізичну силу.

74. Іноді я надаю можливість іншим взяти на себе відповідальність за вирішення спірного питання.

75. Якщо хтось без дозволу візьме мої речі, то обов'язково отримає прочухана.

76. Я втрачаю самовладання в критичній ситуації.

77. Суперечку можна вирішити бійкою.

78. Я рідко даю здачі, навіть якщо хто-небудь вдарить мене.

79. Наївні люди заслуговують на те, щоб їх обдурювали.

80. Я завжди відповідаю криком, якщо на мене кричать.

81. Коли близькі критикують мене, то я дратуюсь та злюсь.

82. Коли хтось знущається з мене, то обов'язково отримає від мене стусана.

83. Коли я злюся, то хочу кого-небудь ударити.

84. Я шукаю шляхи примирення після конфліктної ситуації.

85. Я спокійно реагую на егоїстичних та вихвалькуватих людей.

86. Той хто ображає мене та моїх близьких, напрошується на бійку.

87. Я намагаюсь уникати в розмові висловлювань, які можуть збентежити оточуючих.

88. Я Не здатний вдарити людину.

89. Тільки «слабаки» дотримуються всіх правил і законів.

90. Я відчуваю потребу в екстримальних відчуттях.

91. Іноді я хочу зробити собі боляче.

92. Я не отримую задоволення від відчуття ризику.

93. Я ціную в людях обережність і обачливість.

94. Людина повинна самостійно вирішувати скільки і де хоче випивати.

95. Мені подобаються компанії, де в міру випивають і веселяться.

96. Я З знайомий з люди, які пробували токсичні речовини.

97. Люди повинні взагалі відмовитися від вживання спиртних напоїв.

98. Люди справедливо обурюються, коли дізнаються, що злочинець уник покарання.

99. Мене дратує, коли молодь палить.

100. Я хочу спробувати токсичні речовини за умови, що це не зашкодить моєму здоров'ю і мене не буде покарано.

Обробка та інтерпретація результатів тесту

\section{Ключ до тесту}

Відповіді оцінюються за шкалами наступним чином:

Aгресивність: «Так» - 1, «Hi»-0: 51, 55, 57, 60, 62, 64, 66, 67, 69, 71, 73, 80, 82, 86. «Hi»-1, «Taк»-0:42, 48, 53, 58, 78, 88

Конфліктність: «Так»-1, «Hi»-0: 47, 49, 50, 54, 56, 63, 68, 72, 74, 75, 76, 81. «Hi»-1, «Taк»-0: 46, 52, 59, 61, 65, 70, 84, 85.

тривожність: «Так»-1, «Hi»-0: 6, 9, 12, 15, 24, 30, 32, 35, 37, 39, 44, 45.

«Hi»-1, «Taк»-0: 1, 4, 5, 7, 13, 14, 34, 41.

Дезадаптація: «Так»-1, «Нi»-0: 3, 11, 19, 20, 23, 26, 29, 33, 38, 40.

«Hi»-1, «Taк»-0: 2, 10, 16, 22, 25, 27, 28, 31, 36, 43.

Схильність до девіантної поведінки: «Так»-1, «Hi»- 0: 8, 17, 18, 21, 77, 79, 83, 89, 90, 91, 94, 95, 96, 100. «Hi»-1, «Так»-0: 87, 92, 93, 97, 98, 99.

\section{Інтерпретація результатів тесту}

Агресивність

Низький рівень - 0-5 балів - доброзичливість по відношенню до оточуючих. Вміння володіти власними емоціями і почуттями. 
Середній рівень - 6-14 балів - помірна агресивність. У випадку необхідності особистість проявляє здатність підкоряти своїй волі інших людей, не дозволяє їм керувати собою, вміє протиставити невмотивованій агресії власну - захисна поведінка.

Високий рівень - 15-20 балів - схильність до агресивних імпульсів по відношенню до оточуючих і втрата самоконтролю. Агресивність носить наступальний характер і досить часто $\epsilon$ невмотивованою з боку інших. Неврівноваженість та жорстокість до інших: негативні оцінки оточуючих, підвищення тону, використання лайливих слів, застосування фізичних методів впливу.

\section{Конфліктність} ситуацій.

Низький рівень - 0-5 балів - ухилення від суперечок та конфліктів, уникнення критичних

Середній рівень - 6-14 балів - достатня гнучкість у стосунках з іншими людьми. Готовність до компромісних рішень, конфліктні стосунки для $є$ швидше тактикою, ніж способом життя. Застосування конфліктної поведінки за умови відсутності іншого виходу та засобів вирішення ситуації. Стриманість у висловлюваннях та дотримання межі коректності.

Високий рівень - 15-20 балів - конфлікт як спосіб життя. Важко встановлювати позитивні взаємини з людьми. Прагнення поставити власні інтереси вище за інтереси інших людей і взаємин 3 ними. Неадекватне сприйняття критики з боку інших. Нестриманість та грубість у спілкуванні.

\section{тривожність}

Низький рівень - 0-5 балів - впевненість в собі і своїх силах. Відкритість і гнучкість у взаємодії з оточенням. Готовність приймати сміливі і ризиковані рішення навіть в умовах дефіциту інформації.

Середній рівень - 6-14 балів - відсутні явні ознаки тривожності або невпевненості в собі. Схильність до деякої нерішучості, невпевненості в собі. Характеризується зайвим сумнівами, ретельними повторними оглядами можливих результатів, що може затягувати терміни виконання рішень.

Високий рівень - 15-20 балів - характеризується високим рівнем розвитку самозахисних механізмів і чутливості. Рідко упевнений в чому-небудь до кінця, рідко приймає самостійні рішення, прагне передбачити і прорахувати навіть малоймовірні результати. Стратегія поведінки будується, в основному, з завдання «уникнення невдачі». Віддає перевагу відмовлятися від робіт, в яких успіх не гарантований.

\section{Дезадаптація}

Низький рівень - 0-5 балів - ефективна взаємодія організму із середовищем. Адаптація здійснюється за допомогою конструктивних механізмів та захисних механізмів. Адекватне реагування на зміну соціальних умов життя i утримання відповідності між уявленнями про навколишній світ та уявленнями про себе.

Середній рівень - 6-14 балів - помірний рівень дезадаптації пов'язаний з неможливістю знайти прийнятні способи адаптації в специфічних умовах при вирішенні проблем.

Високий рівень - 15-20 балів - стан стабільної непристосованості особистості, активізує захисні механізми.

\section{Схильність до девіантної поведінки}

Низький рівень - 0-5 балів - невиразність тенденцій до девіантної поведінки або хороший соціальний контроль поведінкових реакцій. Неприйнятність насильства як засобу вирішення проблем. Високий самоконтроль поведінкових емоційних реакцій, чуттєвих потягів.

Середній рівень - 6-14 балів - слабкість вольового контролю емоційної сфери. Готовність до реалізації девіантної поведінки. Схильність до відходу від реальності за допомогою зміни свого психічного стану, про схильність до ілюзорно-компенсаторного способу вирішення особистісних проблем. Протиставлення власних норм і цінностей загальноприйнятим.

Високий рівень - 15-20 балів - надзвичайна вираженість нонконформістських тенденцій. Небажання або нездатність контролювати поведінкові прояви емоційних реакцій. Схильність реалізовувати негативні емоції безпосередньо в поведінці, без затримки. Несформованість вольового контролю своїх потреб і чуттєвих потягів.

Експериментальне дослідження проводилось у містах України. До участі в дослідженні були залучені учасники різноманітних молодіжних субкультур (80 підлітків віком 14-16 років) та особи, які не належать до субкультурального простору (80 респондентів віком від 14 до 16років). Всього в експерименті брали участь 160 осіб.

Надійність та вірогідність результатів дослідження забезпечувалися обгрунтованістю вихідних методологічних положень, теоретичним аналізом наукових досліджень різних авторів вітчизняної та зарубіжної психології, застосуванням апробованого діагностичного інструментарію, 
залученням репрезентативної вибірки, статистичним опрацюванням отриманих результатів. Одержані результати порівнювалися 3 даними спостереження. Отримана система діагностики забезпечує комплексний аналіз проблеми формування особистісних деструкцій у підлітковому віці та отримання достатнього експериментального матеріалу для аналізу.

У ході дослідження було виявлено рівні прояву особистісних деструкцій у представників молодіжних субкультур. Всі вони були обумовлені взаємодією молоді з соціальним середовищем, в якому вони перебувають Узагальнення результатів емпіричного дослідження показало, що у представників молодіжних субкультур на 45\% виражені особистісні деструкції, ніж у підлітків, що перебувають поза субкультуральним оточенням. Підлітки-неформали характеризуються високим рівнем агресивності, що має наступальний характер, неврівноваженістю та жорстокістю до інших: негативні оцінки оточуючих, підвищення тону, використання лайливих слів, застосування фізичних методів впливу. Підлітки, що перебувають поза субкультуральним впливом застосовують агресивність, як захисну поведінку - особистість проявляє здатність підкоряти своїй волі інших людей, не дозволяє їм керувати собою, вміє протиставити невмотивованій агресії власну.

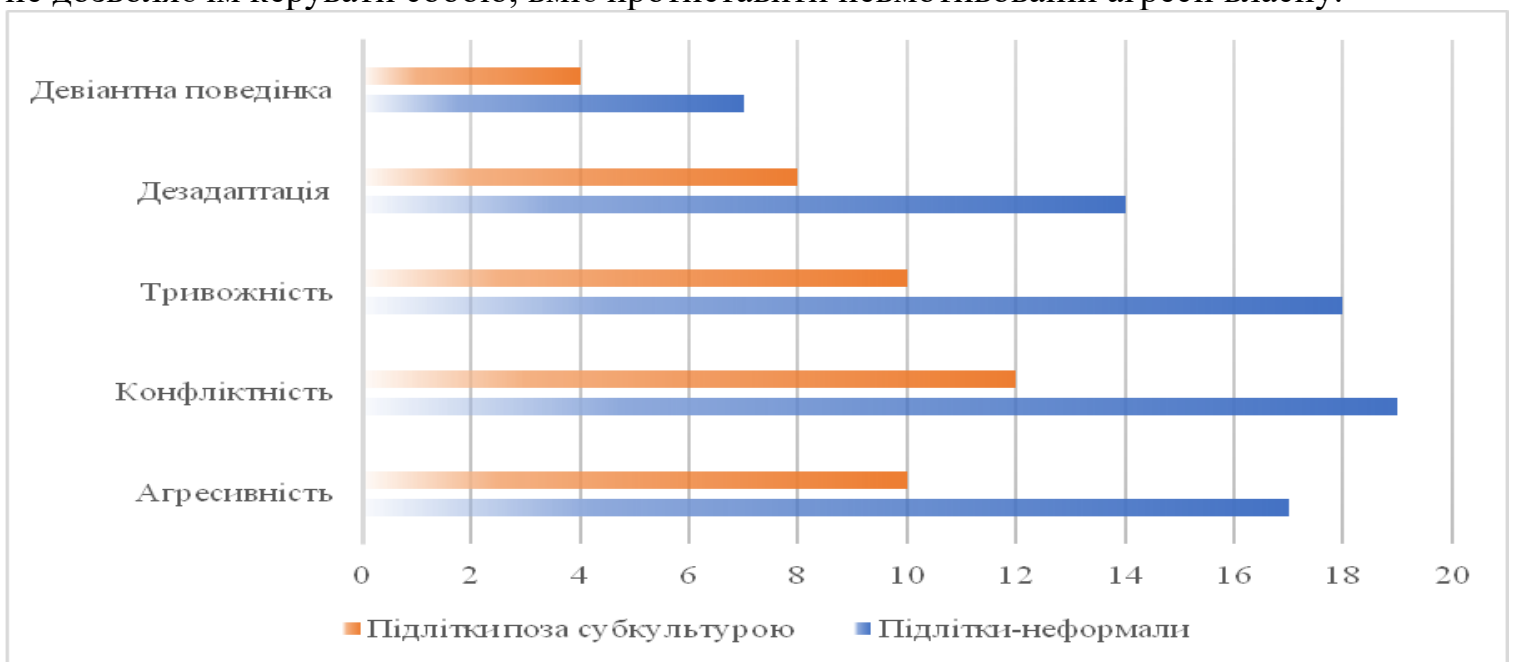

Рис. 1. Рівень розвитку особистісних деструкцій у представників молодізяних субкультур

Представникам молодіжних субкультур важко встановлювати позитивні взаємини з людьми, через прагнення поставити власні інтереси вище за інтереси інших людей і взаємин з ними. Вони неадекватно сприймають критику з боку інших, проявляють нестриманість та грубість у спілкуванні. Як і у випадку 3 агресивністю, підлітки не включені до середовища молодіжної субкультури проявляють достатня гнучкість у стосунках з іншими людьми і застосовують конфліктну поведінку за умови відсутності іншого виходу та засобів вирішення ситуації.

Учасники молодіжних субкультур характеризуються високим рівнем розвитку самозахисних механізмів і чутливості, ніж підлітки, що перебувають поза субкультуральним середовищем, яким притаманний середній рівень тривожності. Підлітки-неформали постійно перебувають у стані стабільної непристосованості особистості, що активізує захисні механізми. Підлітки поза субкультуральним середовищем характеризуються помірним рівнем дезадаптації, що пов'язаний 3 неможливістю знайти прийнятні способи адаптації в специфічних умовах при вирішенні проблем.

У представників молодіжних субкультур надзвичайна вираженість нонконформістських тенденцій, схильність реалізовувати негативні емоції безпосередньо в поведінці, без затримки. Підлітки не включені до середовища молодіжної субкультури характеризуються схильністю до ілюзорно-компенсаторного способу вирішення особистісних проблем та готовністю до реалізації девіантної поведінки, як наслідку слабкого вольового контролю емоційної сфери, що може бути зумовлено $з$ переживанням підліткової кризи розвитку особистості. Підліток, потрапляючи у середовище молодіжної субкультури, переймає іiі норми і правила, стає більш конформним i радикально налаштованим, що в подальшому стає чинником прояву деструктивних поведінкових реакцій. Здатність груп посилювати деструктивні реакції частково пов'язана 3 «розмиванням» відповідальності (уникнення покарання за свої дії). Крім того, групи підсилюють деструктивні схильності значною мірою так само, як вони поляризують й інші тенденції, - через соціальне зараження.

Висновки 3 даного дослідження і перспективи подальших розвідок. Неформальні молодіжні течії мають специфічний вплив на особистість підлітка, який ідентифікує себе як члена певного угруповання. Підлітки зазнають різноманітного впливу молодіжних субкультур на власну 
психіку і процес становлення особистості. Експериментально доведено, що схильність деструктивних поведінкових реакцій є однією з основних соціально-психологічних характеристик представників молодіжних субкультур на індивідуальному рівні поряд 3 високим рівнем агресивності, конфліктності, високою тривожністю, почуттям емоційної ізоляції та несформованістю вольового контролю своїх потреб і чуттєвих потягів.

Проблема впливу субкультур на процес соціалізації особистості підлітків, зокрема формування поведінки, в соціумі посідає одну з головних сходинок до позитивного становлення індивіда у сучасному суспільстві. Виникає потреба пошуку адекватних педагогічних засобів впливу на підлітків-неформалів та корекції деструктивної поведінки.

\section{Список використаних джерел}

1. Аруцев М. А. Молодежная околоспортивная субкультура как социокультурный феномен: автореф. дис. ... канд. соц. наук : 2200.06 - «Социология культуры, духовной жизни (социологические науки)» / М. А. Аруцев. - М., 2007. - 24 с.

2. Зеер Э. Ф. Психология профессиональных деструкций / Э. Ф. Зеер.- Екатеринбург: Деловая кн., 2005. - 240 с.

3. Косарецкая С. В. Неформальные объединения молодежи: Профилактика асоциального поведения / С. В. Косарецкая, С. Г. Косарецкий, Н. Ю.Синягина. - СПб. : КАРО, 2006. - 400 с

4. Лысак И. В. Философско-антропологический анализ деструктивной деятельности современного человека / И. В. Лысак. - Ростов на/Д. : Изд-во СКНЦ ВШ, 2004. - 160 с.

5. Мудрик А. В. Социализация человека : учеб. пособ. для студентов высш. учеб. заведений / А. В. Мудрик. - М. : Академия, 2006. - 288 с.

6. Brake M. The Sociology of Youth Culture and Youth Subcultures (Routledge Revivals): Sex and Drugs and Rock 'n' Roll? / M. Brake. - London : Routledge, 2014. - 216 p.

\section{References}

1. Arucev M. A. Molodezhnaja okolosportivnaja subkul'tura kak sociokul'turnyj fenomen: avtoref. dis. ... kand. soc. nauk : 22.00 .06 - «Sociologija kul'tury, duhovnoj zhizni (sociologicheskie nauki)» / M. A. Arucev. - M., 2007. - 24 s.

2. Zeer Je. F. Psihologija professional'nyh destrukcij / Je. F. Zeer. - Ekaterinburg : Delovaja kn., 2005. $-240 \mathrm{~s}$.

3. Kosareckaja S. V. Neformal'nye ob\#edinenija molodezhi: Profilaktika asocial'nogo povedenija / S. V. Kosareckaja, S. G. Kosareckij, N. Ju.Sinjagina. - SPb. : KARO, 2006. - 400 s.

4. Lysak I. V. Filosofsko-antropologicheskij analiz destruktivnoj dejatel'nosti sovremennogo cheloveka / I. V. Lysak. - Rostov na/D. : Izd-vo SKNC VSh, 2004. - 160 s.

5. Mudrik A. V. Socializacija cheloveka: ucheb. posob. dlja stud. vyssh. ucheb. zavedenij / A. V. Mudrik. - M. : Akademija, 2006. - 288 s.

6. Brake M. The Sociology of Youth Culture and Youth Subcultures (Routledge Revivals): Sex and Drugs and Rock 'n' Roll? / M. Brake. - London : Routledge, 2014. - 216 p.

\section{R. Pavelkiv. DIAGNOSTIC COMPONENT OF PERSONAL DESTRUCTION RESEARCH} OF YOUTH SUBCULTURES REPRESENTATIVES.

The article presents the scientific and theoretical survey of native and foreign researches, devoted to the problem of influence of social factors on the process of personal destruction formation of youth in the system of youth subcultures. An attempt to discover the effect of youth subcultures environment as a psychological determinant of destruction formation had been done, the methods and psychodiagnostic tools of personal destruction components of youth subculture representatives had been introduced, that had become the main source of the author's theoretic and methodological research.

On the empirical level the essence and interconnection of formation mechanisms of destructive forms of personal reacting and their displays at social interaction were established. Social and personal peculiarities of youth subculture influence on a personality of a teenager as one of the driving forces of personal destruction formation had been studied.

The analysis of social behavior deviation of a personality formed under youth groups influence and the analysis of the theory of reasons of deviation rise had been carried out. Presented analysis provides systemic view of personal destruction of youth and promotes the discovery of cause and effect relation of social environment influence on a personality.

Key words: subculture, youth subculture, personal destruction, deformation of a personality, deformed socialization. 